\title{
REFLEXÕES SOBRE O FENÔMENO DOS “NOVOS” DIREITOS FUNDAMENTAIS E AS DEMANDAS TRANSNACIONAIS.
}

\author{
Marcos Leite Garcia ${ }^{1}$
}

\section{RESUMO}

O presente artigo procura demonstrar a conexão existente entre o conceito de "novos" direitos fundamentais e o fenômeno da transnacionalização do Direito. Determina que dita conexão se inicia com o processo histórico da especificação dos direitos fundamentais. Analisa, ademais, o conceito e as características dos novos direitos fundamentais transnacionais e, a partir de uma série de critérios identificadores e determinantes, seleciona quais são as demandas que serão o fundamento de tais direitos. Por fim, apresenta alguns fundamentos para o fenômeno da transnacionalidade que implicará na criação de um novo espaço democrático entre os países e em uma nova visão do Direito.

Palavras-chave: Direitos fundamentais. Novos Direitos. Transnacionalização.

\section{INTRODUÇÃO}

O presente artigo tem como objetivo principal oferecer alguns elementos para que se possa iniciar uma necessária reflexão sobre a questão da construção de um espaço transnacional. Espaço este que gradativamente está se tornando cada vez mais imprescindível para tratar de temas fundamentais de direitos difusos e transfronteiriços como o direito à paz, direito a um meio ambiente saudável, direito à segurança no consumo de bens através de uma economia globalizada, entre outros.

O filósofo alemão Jürgen Habermas no livro Era das Transformações ${ }^{2}$ prevê a construção de novos espaços a partir da perspectiva de ampliação da esfera da influência da experiência das sociedades democráticas para além das fronteiras nacionais. No entender de Habermas tal processo de democratização pode ser reproduzido no que chama de constelação pós-nacional (Die postnationale Konstellation) ${ }^{3}$ pelos caminhos de uma política interna voltada para 0 mundo em geral, ou seja, aberta a uma ordem jurídica cosmopolita ${ }^{4}$, capaz de funcionar sem a estrutura de um governo mundial ${ }^{5}$.

A história recente da economia mundial indica cautela em afirmar como serão as instituições e as relações entre os diferentes blocos de nações que irão compor a Comunidade Internacional. Mesmo assim é inevitável e evidente a necessidade de abordar questões relacionadas ao fenômeno da transnacionalidade, dito de forma mais radical, sem receio a cometer exageros: faz-se vital para o futuro da raça humana tratar das questões que intitulamos de demandas transnacionais.

O fenômeno da transnacionalidade dá-se a partir das chamadas demandas transnacionais que a sua vez estão relacionadas com a questão da efetividade dos chamados direitos difusos e transfronteiriços. Desta maneira, as demandas 
transnacionais são questões fundamentais para o ser humano e que vêm sendo classificadas pela doutrina como "novos" direitos. Um fato é impossível de se evitar: as questões transnacionais devem ser abordadas e enfrentadas por toda a Comunidade Internacional de forma diferente da prevista nas legislações interna e internacional existente.

A discussão sobre as demandas transnacionais em primeiro lugar gira em torno da questão da guerra e da paz. Esta certamente é a primeira grande questão transnacional e difusa da humanidade. Os Direitos Humanos são um fenômeno do mundo moderno e são concebidos e teorizados primeiramente como Direito Natural Racionalista ${ }^{6}$ e será exatamente em um debate sobre o tema de guerra e da paz que Hugo Grotius dará partida ao mesmo ${ }^{7}$. O direito à paz segue sendo, principalmente após o processo de internacionalização dos direitos humanos - demanda oriunda, sobretudo do horror da Segunda Guerra Mundial -, um tema ainda em debate e agora classificado como um direito difuso (e transfronteriço mesmo em sua modalidade quando trata de conflitos internos) ou como pelo menos uma questão difusa, já que existe uma polêmica quanto a classificar a paz como um direito fundamental ${ }^{8}$. As seguintes serão todas demandas mais recentes como a questão do meio ambiente, do Direto dos consumidores, do direito ao desenvolvimento dos povos etc.

\section{DEMANDAS TRANSNACIONAIS, DIREITOS FUNDAMENTAIS E SUAS LINHAS DE EVOLUÇÃO}

As demandas transnacionais se justificam a partir da necessidade de criação de espaços públicos para tratar de questões referentes a fenômenos novos que serão ineficazes se tratados somente dentro do espaço do tradicional Estado nacional. Estes fenômenos novos se identificam com os chamados "novos" direitos ou "novos" direitos fundamentais. Para evitar equívocos de fundo meramente ideológico, certamente que se faz necessário afirmar que as demandas transnacionais não tratam somente de questões relacionadas com a globalização econômica como alguns autores pretendem, e sim com fundamentais questões de direitos relacionadas com a sobrevivência do ser humano no planeta. A globalização econômica pode estar na base de algumas questões transnacionais, mas não é sua principal fonte e fundamentação, a principal justificativa da necessidade de transnacionalização do direito é a necessidade de proteção do ser humano e dentro dessa perspectiva também se encontra a proteção de seu entorno natural.

Os direitos fundamentais são um fenômeno da Modernidade, pois as condições para o seu florescimento se dão no chamado trânsito à modernidade, conforme a tese das linhas de evolução desenvolvidas pelo professor Peces-Barba ${ }^{9}$. Assim depois do primeiro processo de positivação que será marcado pelas revoluções burguesas e pela ideologia liberal, através da história dos dois séculos seguintes os direitos fundamentais irão se modificando e incluindo novas demandas da sociedade em transformação. Os direitos fundamentais não são um conceito estático no tempo e sua transformação acompanha a sociedade humana e conseqüentemente suas necessidades de proteção.

Cabe frisar que na Modernidade os direitos humanos nascem como direitos fundamentais, ou seja, primeiramente são concebidos como direito interno ${ }^{10}$, como 
direitos do cidadão, mas ainda que direito nacional-interno com ampla vocação e pretensão universal como direitos do homem genérico, se referindo a todos os seres humanos. O fenômeno da universalidade dos direitos humanos é diferente do fenômeno da internacionalização dos mesmos. A universalização é anterior aos mesmos, pois se dá já na construção teórica dos direitos, ainda como Direito Natural Racionalista, e segue seu curso desde as primeiras declarações de direitos ${ }^{11}$. Já a internacionalização dos Direitos Humanos é um processo muito mais recente, pois se dá basicamente como resultado da barbárie da guerra, do desejo do nunca mais da Segunda Guerra Mundial, com o advento da Organização das Nações Unidas (ONU) e com a construção de pelo menos três sistemas internacionais de proteção de Direitos Humanos (ONU, Organização dos Estados Americanos e Conselho da Europa) e tem como marco documental inicial a fundamental Declaração Universal de Direitos Humanos de $1948^{12}$. Não resta a menor dúvida de que a manutenção da paz e a defesa dos direitos humanos, objetivos plasmados no art. $1^{\circ}$ da Carta de São Francisco de 1945, decisivamente são os principais motivos da criação da ONU. Da mesma forma que essas foram também as principais preocupações tanto da Comunidade Interamericana como Européia. Não resta dúvida que a questão da universalidade do conceito ocidental dos direitos humanos/direitos fundamentais ${ }^{13}$ é uma discussão prévia ao tema da transnacionalidade dos mesmos.

A transnacionalização dos direitos fundamentais é um processo diferente e posterior ao da internacionalização dos mesmos. Na teoria geral dos direitos fundamentais do professor Gregorio Peces-Barba uma das mais importantes de suas teses consiste nas já mencionadas linhas de evolução dos direitos que são relatadas nos seguintes processos, entre os quais incluímos didaticamente - em um outro escrito - um anterior por nós chamado processo de formação do ideal dos direitos fundamentais ${ }^{14}$. Resumidamente as linhas ou processos evolutivos dos direitos fundamentais em Peces-Barba se dão em quatro processos históricos: 1. processo de positivação: a passagem da discussão filosófica do Direito Natural Racionalista ao Direito positivo realizada a partir das revoluções liberais burguesas (característica principal: positivação da primeira geração dos direitos fundamentais: direitos de liberdade); 2. processo de generalização: significa a extensão do reconhecimento e proteção dos direitos de uma classe a todos os membros de uma comunidade como conseqüência da luta pela igualdade real (característica principal: a luta e a conseqüente positivação dos direitos sociais ou de segunda geração e de algumas outras liberdades como a de associação e a de reunião e a ampliação da cidadania com a universalização do sufrágio); 3. processo de internacionalização: louvável tentativa de internacionalizar os direitos humanos e criar sistemas de proteção internacional dos mesmo que estejam por cima das fronteiras e abarquem toda a Comunidade Internacional ou regional dependendo do sistema. Infelizmente trata-se de um processo estagnado por vários problemas que caracterizam o Direito Internacional dos Direitos Humanos e de difícil realização prática (Principal característica: tentativa de efetivar a universalização dos direitos ao positivar os direitos humanos no plano internacional). 4. processo de especificação: atualíssimo processo pelo qual se considera a pessoa em situação concreta para atribuir-lhe direitos seja: como titular de direitos como criança, idoso, mulher, consumidor, etc., ou como alvo de direitos como o de um meio ambiente saudável ou à paz (principal características: positivar e mudar a mentalidade da sociedade na direção dos chamados direitos de solidariedade, difusos ou de terceira geração) ${ }^{15}$. 
A internacionalização dos direitos fundamentais em direitos humanos é um fenômeno ainda incompleto e para muitos um falido processo de tentativa de internacionalizar a questão. Sua principal crítica situa-se na falta de um poder coercitivo acima dos Estados e na falta de homogeneidade entre os países e os seus interesses, que leva a uma carência de democracia no contexto da Comunidade Internacional: o que deixa infelizmente prevalecer a situação da tradicional, primitiva e selvagem lei do mais forte que impõe sua vontade. Este processo incompleto situa-se exatamente em um âmbito jurídico que carece de um Poder político que garanta plenamente a eficácia do ordenamento internacional dos diferentes sistemas de proteção dos direitos humanos, ainda que as tentativas são válidas e muito interessantes ${ }^{16}$. Difícil conceber o Direito sem força, sem coerção. Mesmo assim, inegável é a existência de um Direito Internacional dos Direitos Humanos, como nos mostra a prática e a jurisprudência interna e internacional e como admite majoritariamente a doutrina. Não se pode negar a existência de normas internacionais de direitos humanos, ainda que é facilmente constatado - exatamente pelos problemas apontados - um absurdo e completo descaso com este ordenamento muito menos considerado e obedecido que os ordenamentos internos.

\section{PRINCIPAIS CARACTERÍSTICAS DOS “NOVOS” DIREITOS}

Algumas questões são diferenciadoras dos chamados direitos fundamentais de terceira geração, também chamados de "novos" direitos. Devido as suas especiais condições, diferentes dos demais direitos fundamentais como foi visto, os "novos" direitos são: individuais, coletivos e difusos ao mesmo tempo, por isso considerados transindividuais. São transfronteiriços e transnacionais, pois sua principal característica é que sua proteção não é satisfeita dentro das fronteiras tradicionais do Estado nacional. São direitos relacionados com o valor solidariedade. Requerem uma visão de solidariedade, sem a mentalidade social de solidariedade não podemos entender os direitos difusos. Na visão de Carlos de Cabo Martín a noção do valor solidariedade é uma característica essencial, um princípio básico, do constitucionalismo do Estado social de Direito ${ }^{17}$. Certamente que é impossível pensar em um direito fundamental coletivo e/ou difuso sem a consideração do valor solidariedade.

No dizer de Maria José Añón Roig, os direitos de terceira geração são direitos difusos, coletivos e individuais ao mesmo tempo. Os direitos da liberdade são direitos individuais, os direitos de igualdade são direitos individuais e coletivos e os direitos de solidariedade seriam direitos individuais, coletivos e difusos ao mesmo tempo ${ }^{18}$. Dando assim a exata noção de que todos os direitos fundamentais são universais, indivisíveis, interdependentes e inter-relacionados (De acordo com o ponto 1.5 da Declaração e Programa de Ação de Viena aprovado pelo Plenário da Conferência Mundial dos Direitos Humanos, em 25 de Julio de 1993).

Ademais como foi dito, os direitos de solidariedade são difusos, ou seja, em conformidade com o que foi dito, além de serem coletivos são difusos. Então se faz necessário estabelecer a diferença entre direitos difusos e direitos coletivos: em primeiro lugar, no caso dos direitos difusos são incontáveis os seus titulares ou pessoas que podem ser atingidas; já no caso dos direitos coletivos ao contrário podemos estabelecer o número de titulares ou de as pessoas atingidas no caso de desrespeito de determinado direito coletivo. Por exemplo, com a ajuda dos números 
da Fundação Instituto Brasileiro de Geografia e Estatística pode-se estabelecer o número de trabalhadores brasileiros ou de trabalhadores que atuam na República Federativa do Brasil, ou fazer uma estimativa sobre o número de desempregados em um país ou aqueles que trabalham na economia informal. No caso dos direitos da chamada terceira geração, exatamente por serem difusos, não se sabe ao certo o número de pessoas envolvidas nessas questões. Por exemplo, no caso de uma catástrofe nuclear, nunca se sabe o número de pessoas realmente atingidas em dito tipo de desastre ambiental, se toda a população de uma cidade, de uma província, de uma região, de um país, de dois ou mais países, de todo um continente ou mesmo de todo o planeta. No caso da contaminação de um rio, esse rio pode passar por muitas províncias de um mesmo país, ou mesmo por vários países. Enfim são incalculáveis os danos causados pela violação de um direito difuso, assim como são incontáveis os números de vítimas das violações dos direitos difusos ${ }^{19}$. Em contrapartida, já as violações de um direito coletivo se podem estabelecer os números das vítimas atingidas.

Além de que os direitos difusos são transfronteiriços, segundo boa parte da doutrina européia, eles em nossa opinião são também algo mais que isso. Certa é a afirmação de que os direitos fundamentais de terceira geração devem ter um tratamento diferenciado por perpassarem as fronteiras, por isso têm a característica de serem transfronteiriços. Mas se consideramos estes somente como transfronteiriços, eles poderiam ter unicamente um tratamento internacional a partir do Direito Internacional tradicional. Enfim eles ademais são transnacionais. Exatamente por serem transfronteiriços e difusos, seu tratamento deve ou também pode, por uma questão de efetividade, ser transnacionalizado. Ou seja, seu tratamento deve ser a partir de um Direito Transnacional ${ }^{20}$. Transnacional no sentido como muito bem lecionam Paulo Márcio Cruz e Zenildo Bodnar: "o prefixo trans denota (...) a capacidade não apenas da justaposição de instituições ou da superação/transposição de espaços territoriais, mas a possibilidade da emergência de novas instituições multidimensionais, objetivando a produção de respostas mais satisfatórias globais contemporâneas" ${ }^{21}$. Seguem os professores catarinenses, "Dessa forma, a expressão latina trans significaria algo que vai 'além de' ou 'para além de', a fim de evidenciar a superação de um locus determinado que indicaria (...) um constante fenômeno de desconstrução e construção de significados" ${ }^{22}$. Ainda os professores catarinenses fazem uma importante diferenciação do prefixo trans com relação ao prefixo inter. "diversamente da expressão inter, a qual sugere a idéia de uma relação de diferença ou aproximação de significados relacionados, o prefixo trans denota a emergência de um novo significado construído reflexivamente a partir da transferência e transformação dos espaços e modelos nacionais" ${ }^{23}$.

Acertadamente os professores Paulo M. Cruz e Zenildo Bodnar aludem a que todas essas questões são urgentes, uma vez que a causa da destruição de nosso entorno natural, a questão da paz e do consumo global de bens, por exemplo, são todas questões que trazem consigo uma necessidade de imediata e efetiva defesa e por isso mesmo a construção de espaços transnacionais é uma emergência de nossa era. De nada adiantaria, por exemplo, uma nação cuidar e ter uma excelente legislação e consciência social solidária e consciência ecológica no seio de seu povo, se o país vizinho não a tem, pois ficará a mercê da poluição causada por seus vizinhos. Então a conscientização e legislação ambiental têm que ter um tratamento transnacional e ser compartida entre todos os membros da comunidade - seja 
regional ou internacional - para cuidar das questões ambientais e de outras questões dos direitos provenientes do processo de especificação.

É correto o que afirma o professor Antonio Pérez Luño quando diz que as estratégias reivindicativas dos direitos humanos se apresentam hoje com características inequívocadamente inovadores ao serem polarizadas em torno a temas como direito à paz, direito dos consumidores, direito a um meio ambiente saudável, direito à manipulação genética, direito à qualidade de vida ou à informática $^{24}$. Não resta dúvida que a revolução tecnológica, em palavras de Pérez Luño, "há redimensionado as relações do homem com os demais homens e a natureza, assim como as relações entre o ser humano com seu contexto ou marco cultural de convivência" ${ }^{25}$. Evidentemente que essas mudanças não hão de deixar de influenciar ou de incidir no entorno dos direitos fundamentais.

\section{CARACTERÍSTICAS DO PROCESSO DE ESPECIFICAÇÃO E OS DIREITOS FUNDAMENTAIS TRANSNACIONAIS}

Com a consideração do processo de especificação dos direitos fundamentais podemos explicar uma série de modificações referente aos direitos e uma nova visão e concepção dos mesmos será necessária. A transformação que o fenômeno dos "novos" direitos trás à concepção dos direitos fundamentais é muito bem explicada através da quarta linha de evolução através da terminologia proposta primeiramente por Noberto Bobbio ${ }^{26}$ e desenvolvida pelo professor Gregorio PecesBarba como processo de especificação. Nas palavras do último poderíamos até falar de um processo de concreção, uma vez que supõe não somente a seleção e matização dos processos anteriores, senão que a inclusão de novos elementos que levam ao enriquecimento e a complementação dos anteriores grupos de direitos fundamentais $^{27}$. O jusfilósofo italiano Norberto Bobbio destaca que a especificação se produz na direção dos titulares ${ }^{28}$ e o jusfilósofo espanhol Gregorio Peces-Barba também considera a direção dos titulares e destaca que a especificação dos "novos" direitos em relação aos conteúdos dos mesmos. Ambos jusfilósofos concordam que a especificação dos direitos se insere como transformadora da visão dos direitos fundamentais e por isso que dá uma nova face à cultura política e jurídica moderna; ou como diz o professor Pérez Luño: agora já pós-moderna ${ }^{29}$. Em nossa opinião o fenômeno da transnacionalização do direito a partir de demandas transnacionais está mais intimamente conectado com o processo de especificação quanto ao conteúdo, ainda que não devemos olvidar que as questões de especificação quanto aos titulares também são de direitos fundamentais transnacionais.

3.1. Demandas transnacionais de direitos fundamentais especificadas quanto ao titular.

Em relação primeiramente aos titulares os direitos fundamentais se especificam na busca de uma melhor igualdade de condições ou igualdade de oportunidade para todos. É a questão de tratar a desiguais de forma desigual para se chegar a uma igualdade. Quanto aos titulares é constatável que alguns grupos por diversos motivos estão em situação de desigualdade e merecem uma proteção especial para chegar a uma teórica igualdade. É o caso das mulheres, dos idosos, das crianças e dos adolescentes, dos indígenas e de grupos minoritários outro como deficientes físicos e mentais e parcelas menos favorecidas da população de determinados 
povos (como afro-descendentes, pobres e excluídos). São todas questões absolutamente polêmicas, sobretudo para sociedades de modernidade $\operatorname{tardia}^{30}$ como a brasileira acostumada ao descaso que sofrem os menos favorecidos e com os arraigados privilégios dos donos do poder, utilizando-se aqui propositalmente o título da magistral obra de Raymundo Faoro ${ }^{31}$. Ainda que no caso brasileiro a incompreensão se deve, sobretudo, ao egoísmo dos mais favorecidos, a polêmica é compreensível em certa medida já que é uma mudança paradigmática no consenso sobre os direitos fundamentais que, como se sabe, tem uma importância decisiva na configuração da cultura jurídica da Modernidade. Na primeira geração dos direitos os titulares eram os genéricos homens e cidadãos e a cidadania era dividida em ativa e passiva (a idéia de sufrágio censitário), na segunda geração este é visto com relação à sua ocupação, além de homem e cidadão agora ele é também trabalhador, um cidadão que é titular de algumas necessidades básicas e que reivindica não somente estas, mas também seu direito de participação política (a luta pela universalização do sufrágio). Dentro da perspectiva de Luigi Ferrajoli no sentido de que os direitos fundamentais são reivindicações dos mais débeis ${ }^{32}$, os direitos fundamentais de terceira geração, originados no processo de especificação, agora são reivindicados pelos menos favorecidos na sociedade contemporânea, não pelo mais forte e sim por coletivos dos mais débeis: a mulher, a criança, o idoso, 0 indígena, o negro etc.

Segundo o professor Peces-Barba ${ }^{33}$ são três os critérios para identificar esses coletivos, as chamadas circunstâncias ou situações cuja relevância deriva: 1. De uma condição social ou cultural de pessoas que se encontram em situação de inferioridade nas relações sociais e que necessitam de uma proteção especial; 2 . De uma condição física de pessoas que por alguma razão se encontram em uma situação de inferioridade nas relações sociais; 3. E de uma situação específica que ocupam as pessoas em determinadas relações sociais.

Em primeiro lugar (critério 1.) Peces-Barba fala de uma condição social ou cultural de pessoas que se encontram em situação de inferioridade nas relações sociais e que necessitam de uma proteção especial, uma garantia ou uma promoção especial para superar a discriminação, o desequilíbrio ou a desigualdade. $O$ modelo mais claro e consagrado é o exemplo do direito da mulher. ${ }^{34}$ Neste mesmo grupo podemos situar os direitos do emigrante, do afro-descendente, do indígena etc. No caso brasileiro além das mulheres temos uma série de outros grupos de pessoas que merecem uma proteção especial, pelo menos para se chegar a uma igualdade de oportunidade para esses grupos que são os pobres, os excluídos, os negros e os indígenas etc., evidentemente que é o caso das ações afirmativas, que aqui se fundamentam suas políticas de discriminação positiva. O dilema e o problema em nossa sociedade é como são feitas ditas ações afirmativas na prática e não sua fundamentação.

Em segundo lugar (critério 2.) o professor espanhol fala de uma condição física de pessoas que por alguma razão se encontram em uma situação de inferioridade nas relações sociais. Ditas condições obrigam a uma proteção especial não vinculada ao valor igualdade, mas sim ao valor da solidariedade ou fraternidade ${ }^{35}$. Ainda Peces-Barba leciona que podem ser de dois tipos: gerais e específicos. As condições gerais afetam a todas as pessoas durante algum determinado tempo de suas vidas, enquanto que as condições específicas afetam a algumas pessoas 
durante todo o tempo em alguns casos e somente por algum tempo em outros casos. No suposto das condições relevantes gerais temos como exemplo os direitos da criança e do adolescente, enquanto que no suposto das condições relevantes específicas temos como exemplo os direitos de pessoas que sofrem algum tipo de deficiência permanente ou não. Além do direito do deficiente físico ou mental, também nesse último caso entraria o exemplo do direito dos enfermos e o direito do idoso ${ }^{36}$.

Em terceiro e último lugar (critério 3.), Peces-Barba fala de uma situação específica que ocupam as pessoas em determinadas relações sociais. Referem-se aos grupos genéricos homens ou cidadãos quando se encontram em uma circunstância concreta, são direitos do individuo colocado em uma situação concreta de desvantagem que se justifica quando a outra parte da relação tem um papel preponderante, hegemônico ou de enorme superioridade que exige equilibrar dita relação por meio de uma proteção reforçada. Desta forma nos encontramos diante dos direitos do consumidor situado diante dos grandes monopólios, grandes companhias multinacionais ou nacionais, ou mesmo de grupos de comerciantes e industriais muito mais poderosos que o usuário de seus produtos ${ }^{37}$. Não resta dúvida que este usuário tem seus direitos, ou seja: é titular de direitos, e que está em uma temerosa situação de desigualdade na relação e ademais de que está quase sempre muito desinformado sobre os bens que consome. Da mesma forma está muitas vezes em condições iguais de inferioridade o cidadão diante de serviços estatais públicos. Aqui se desenvolve o valor igualdade no âmbito de uma sociedade consumista e de mercado com a finalidade de paliar seus desajustes.

Nas três circunstâncias descritas pelo professor Peces-Barba estamos diante de situações sociais que por razões culturais, físicas ou psicológicas e da posição em que se encontra a pessoa na sociedade, levam a uma suposta debilidade que o Direito tenta corrigir ou pelo menos diminuir. Podemos afirmar que a questão da igualdade é invocada, sobretudo, no sentido de igualdade de oportunidade. Evidentemente que, como já foi dito, em uma sociedade patrimonialista e estruturada em preconceitos classistas como a brasileira, ditas questões geram muita polêmica.

A questão da titularidade dos direitos fundamentais tem sua relevância primordial na questão da transnacionalidade no sentido de que a mesma significa também uma grande mudança na forma de pensar o Direito. Agora o titular não mais seria o cidadão nacional de um determinado país, aquele que tem a sorte de nascer em um país rico e democrático nem mesmo o genérico homem do direito internacional tradicional, o titular seria o cidadão transnacional. Não cabe dúvida que a transnacionalização somente tem sentido se reforçar a defesa dos direitos fundamentais, a defesa das liberdades aliada à defesa da igualdade perante a lei. Enfim: a transnacionalização do Direito deve proteger os titulares dos direitos fundamentais ${ }^{38}$.

3.2. Demandas transnacionais de direitos fundamentais especificadas quanto ao conteúdo.

Em segundo lugar com relação à especificação dos direitos fundamentais, estes são especificados quanto ao conteúdo. Em nossa opinião é quando são mais claras as demandas transnacionais e cronologicamente algumas de suas demandas 
são até anteriores às demandas especificadas quanto ao titular, ainda que outras sejam mais recentes, então preferimos por esse último motivo deixar estas em segundo lugar. As demandas relativas ao processo de especificação quanto ao conteúdo em princípio são em um primeiro momento basicamente três: o direito à paz, a questão ambiental e o direito ao desenvolvimento dos povos. Posteriormente e mais recentemente nascem outras questões fundamentais de especificação quanto ao conteúdo dos direitos: são os "novos" direitos referentes à biotecnologia, à bioética e à regulação da engenharia genética. Trata dos direitos específicos quanto ao conteúdo que têm vinculação direta com a vida humana, como reprodução humana assistida (inseminação artificial), aborto, eutanásia, cirurgias intra-ulterinas, transplantes de órgãos, engenharia genética (clonagem), contracepção e outros. Também entrariam em essa terceira geração os "novos" direitos advindos das tecnologias de informação (intenet), do ciberespaço e da realidade virtual em geral. Tanto dita questão do Direito à informática como as questões de bioética ou biodireito incluímos, como o faz expressamente o professor Pérez Luño, como direitos de terceira geração, como resultantes do processo de especificação quanto ao conteúdo como o faz o professor Peces-Barba, e não como uma quarta e quinta geração como o fazem alguns renomados autores ${ }^{39}$. Preferimos inclusive nomear essas duas questões mais recentes como "novíssimos" direitos de terceira geração.

Uma classificação tradicional dos direitos divide os mesmos em vários grupos que, em termos cronológicos, se correspondem, mais ou menos, com suas gerações históricas. Ainda que como é sabido, as classificações são sempre não imprecisas e injustas, essa divisão dos direitos em gerações não reproduz exatamente o que aconteceu na histórica. Mas, para esquematizar didaticamente o evoluir do ideal dos direitos alguns autores, como os pioneiros da expressão Vasak e Bobbio, falam de sucessivas gerações dos mesmos ${ }^{40}$. Certamente que é uma terminologia discutível, uma vez que poder-se-ia entender que as gerações são extintas a conseqüência do surgimento de outras, já que normalmente uma geração supera a outra. Crítica bastante comum e que por este motivo alguns autores preferem a expressão dimensões de direitos fundamentais ${ }^{41}$. Em sentido contrário Antonio-Enrique Pérez Luño é um dos teóricos que mais defendem as gerações dos direitos. Para o professor Pérez Luño não significa que uma geração substitua a outra, muito pelo contrário senão que em ocasiões o aparecimento de novos direitos traduzem exatamente o contrário: são respostas às necessidades históricas; e outras vezes supõem redimensionamentos ou redefinições de direitos anteriores para adaptá-los a novos contextos em que devem ser aplicados ${ }^{42}$. Da mesma forma o professor Gregorio Peces-Barba reduz as críticas das gerações na alusão às linhas de evolução dos direitos no sentido de que as mesmas não significam a superação de uma geração pela outra e que tal consideração vem a ser muito didática ${ }^{43}$. Então se entendemos que assim acontece: uma geração não supera as outras, uma vez que as anteriores seguem vivas e se integram com as novas, e que não existe de forma alguma hierarquia entre esses grupos de direitos fundamentais ${ }^{44}$, existe sim uma integração das gerações, dimensões como querem alguns ou grupos de direitos fundamentais (teoria integral dos direitos fundamentais) ${ }^{45}$. Seguindo a visão do professor Pérez Luño diríamos então que estamos, no caso das demandas transnacionais, diante da terceira geração dos direitos ${ }^{46}$.

Assim desta feita como os direitos das duas gerações anteriores respondem a valores consagrados como a liberdade e a igualdade, a partir da formulação de uma 
síntese da democrática liberdade igualitária podemos afirmar que os direitos de terceira geração têm seu fundamento no valor solidariedade. Uma solidariedade, que é a forma contemporânea de entender a fraternidade da trilogia da Revolução Francesa. Nas palavras do professor Gregorio Peces-Barba ditos conteúdos que compõe os direitos de terceira geração se formam em nossa era através de três grandes contribuições do ponto de vista ético e político que são as sucessivas ideologias liberal, democrática e socialista ${ }^{47}$.

Como já foi dito, o primeiro direito fundamental especificado quanto ao conteúdo é a questão da paz que está na base mesmo do surgimento do Direito Natural Racionalista. Os principais documentos internacionais sobre o discutido direito à paz ${ }^{48}$, traduzidos sobretudo na intenção de evitar as guerras como a Carta da ONU, assim como todo o processo de internacionalização dos direitos são fruto do "nunca mais" à barbárie nazi-fascista que provocou a Segunda Guerra Mundial. Alguns teóricos rechaçam o direito à paz como um direito humano afirmando que 0 uso da guerra é de fundamental importância para a manifestação da paz e a defesa dos próprios direitos fundamentais; como exemplo, o professor Peces-Barba segue esse entendimento ${ }^{49}$. Outros, os pacifistas, defendem a existência de um direito à paz dentro da perspectiva de um mundo sem armas e conseqüentemente menos violento. Entre estes últimos destacamos os pacifistas institucionais na linha de Luigi Ferrajoli $i^{50}$ - evidentemente que não se trata de mais um pacifismo do tipo absoluto e utópico de um mundo sem armas habitado somente por pessoas boazinhas ${ }^{51}$-. O pacifismo institucional entende o direito como ferramenta crítica contra a guerra e rechaça absolutamente a solução das controvérsias pela violência. Dito pacifismo advoga por um direito penal internacional mínimo e por um constitucionalismo global que proíba e puna a guerra e milita em um movimento contra a normalização constitucional da guerra fundamentado na oposição substancial entre Direito e guerra, uma vez que dita postura classifica os conflitos bélicos de ilegais ${ }^{52}$.

Nossa posição pacifista segue a linha de Ferrajoli, ademais dos conceitos e reflexões do jusfilósofo italiano devemos da mesma maneira ter em consideração a questão de que uso dos direitos humanos contra os próprios direitos humanos ${ }^{53}$, assunto de suma importância na reflexão dos Direito Internacional dos Direitos Humanos de nossa era, e que ajudará na argumentação e fundamentação de um direito à paz em um mundo sem armas, ou sendo realista com menos armas, mas que deve tratar aos intolerantes com a intolerância das armas a partir de tribunais penais internacionalizados ou mesmo de vários tribunais penais regionais ou transnacionalizados. A responsabilidade por crimes de guerra, crimes de lesa humanidade e todos os demais tipos penais internacionais classificados pelo Estatuto de Roma do Tribunal Penal Internacional ${ }^{54}$ não devem estar sujeitos somente às cortes nacionais como querem os países que sistematicamente violam as normas internacionais de direitos humanos e de direito internacional humanitário ${ }^{55}$.

O tema do direito à paz é pouco tratado pela doutrina, como argumenta Maria Eugenia Rodríguez Palop ${ }^{56}$. De todas as maneira a partir das reivindicações pacifista é um tema a ser aprofundado, ainda mais que no pós-guerra chegamos ao absurdo da proliferação das armas nucleares com as quais podemos simplesmente fazer com que todo o planeta seja destituído ou que se transforme em um imenso cemitério ${ }^{57}$. Dita questão, conjuntamente com o uso dos direitos humanos contra os 
direitos humanos, nos leva ao que o professor Pérez Luño ensina sobre a avançada tecnologia faz como o giro copérnico nas relações inter-humanas também com relação ao direito à paz, uma vez que a potencialidade das modernas tecnologias da informação permitem, pela primeira vez, estabelecer formas de comunicação a escala planetária ${ }^{58}$. Segue o professor de Sevilha: "Isso possibilitou que se adquirirá uma consciência universal dos perigos mais imediatos e terríveis que ameaçam a sobrevivência da espécie humana" ${ }^{59}$. Daí que a temática da paz tenha adquirido um inquestionável protagonismo no sistema de necessidades insatisfeitas dos homens e dos povos dos anos de nossa era, e que a temática entranhe uma imediata projeção como direitos fundamentais ${ }^{60}$.

A segunda questão do processo de especificação é a relativa aos direitos relativos ao meio ambiente, que expressam a necessidade de uma solidariedade não somente com nossos contemporâneos, senão que também com relação às futuras gerações para evidentemente evitar a tragédia que seria deixar o legado de um mundo deteriorado e inabitável por motivos de uma absurda contaminação do planeta e de uma egoísta exploração abusiva dos recursos naturais. É a questão transnacional por excelência, e é uma questão mais que urgente de todas, pois sem o planeta, nossa casa, não poderemos viver, evidentemente que é uma questão urgentíssima. Também é a questão difusa por excelência: o uso irracional de um recurso natural, como água, por exemplo, poderá privar até as futuras gerações de este bem natural fundamental. A causa da proteção do meio ambiente, sua reivindicação e sua transformação na mentalidade do ser humano e nos meio produtivos, certamente é a mais imprescindível questão transnacional uma vez que o futuro da raça humana poderá ser sua extinção com a destruição dos elementos que mantém o equilíbrio da natureza. A consciência que fazemos parte da natureza é de fundamental importância, a mudança de mentalidade aqui é vital para toda a raça humana.

Destacam-se algumas características de suma importância do direito ambiental, segundo Martín Mateo ${ }^{61}: 1$. O direito ambiental tem um caráter sistemático, fundamentado em um substrato ecológico, a sua vez voltados na direção da defesa da biodiversidade. É então um ramo do Direito independente que compreende uma percepção global da natureza, como na Alemanha deveria ser utilizada a expressão Direito ecológico; 2. Possui uma espacialidade singular, devido a que abarca questões globais, questões difusas como foi visto, e por isso o campo de atuação perpassa o mero Estado nacional, sendo questão sumamente transnacional ou internacional. Essa é sua principal característica, sua principal razão de existência sem prejuízo de outras normas nacionais ou territoriais. 3. Cada vez mais se externa sua ênfase preventiva diante do aspecto retributivo das infrações ambientais. Desta maneira cada vez mais uma maior ênfase se dá às medidas garantistas e preventivas que evitem as possíveis ou futuras agressões, por motivo de que tais agressões ao entorno podem ter um custo irreparável a valores imensuráveis como a própria vida humana ou o ecossistema circundante. A idéia de danos irreversíveis deve superar a mera quantificação em dinheiro que o Direito possa determinar como indenização. Trata-se, portanto, de um novo ramo independente do Direito; um direito difuso e que deve ter um acentuado caráter educativo para ser preventivo; um direito de solidariedade, de conscientização solidária, que requer uma mudança de mentalidade. 
Uma questão tratada desde o plano internacional, mas que deveria ser reforçada desde o plano do Direito transnacional, os efeitos dos danos ao meio ambiente são a melhor explicação do que venha a ser uma questão difusa, transfronteiriça e transnacional, já que a destruição do meio ambiente não se detém nas fronteiras do país que originou a mesma. Os exemplos são muitos como um acidente nuclear como o de Chernobyl, a poluição de um rio que passa em vários países, a contaminação do mar que banha diversas regiões etc. Alguns exemplos atuais e urgentes: a questão da bacia do Amazonas, sua exploração e seu entorno, somente pode ter um tratamento transnacional pelos países que compõe essa importante área do planeta. Ou mesmo o desastre ambiental do Mar de Aral, situado na fronteira entre o Uzbequistão e o Cazaquistão, certamente uma das maiores catástrofes ecológicas de todo os tempos quando o mar interno perdeu nos últimos 40 anos $80 \%$ de sua área. O exemplo recente do problema ecológico que pode provocar a instalação de uma grande fábrica de celulose no Rio Uruguai do lado uruguaio, na cidade de Fray Bentos, certamente que é um problema transnacional que deveria ter levado em conta todo o entorno e o lado argentino também. Não cabe dúvida que estas são todas questões ambientais transnacionais.

A convicção de que a vida convencional do cidadão contemporâneo ocidental e o seu consumo exagerado de bens industrializados levarão a uma deterioração mais rápida da natureza juntamente com o modelo de desenvolvimento proposto pelo capitalismo dos paises mais industrializados e agora inserido em países emergentes superpopulosos como a China e a Índia, por exemplo, levarão da mesma forma a uma destruição sem precedentes e infelizmente cada vez mais rapidamente. Todas questões urgentíssimas e de impossível resolução nos parâmetros do atual Direito nacional por se tratarem de questões transindividuais, difusas, transfronteriças e transnacionais.

A seguinte questão do direito ao desenvolvimento está amplamente vinculada com a duas questões anteriores já que polemiza com o paradigma de modelo de desenvolvimento seguido pelos paises mais ricos e que está sendo seguido pelos paises subdesenvolvidos e emergentes. O direito ao desenvolvimento dos povos é um direito um pouco esquecido pela doutrina, mas se trata de um tema fundamental para o futuro da humanidade e do planeta. Algumas questões estão radicalmente relacionadas como a da imigração econômica dos povos mais pobres ao ocidente, a da paz, a da sustentação de um meio ambiente nos países periféricos, etc.

Estão na raiz do direito ao desenvolvimento os valores de fraternidade/solidariedade e de igualdade, e supõe em certo modo uma aplicação aos povos no mesmo sentido que tem aos indivíduos os direitos econômicos, sociais e culturais ${ }^{62}$. Seu principal argumento é o que na comunidade de nações se devem generalizar as liberdades e a democracia, tanto nas suas relações como no interior dos países. O direito ao desenvolvimento internamente se traduz em direitos sociais vistos desde uma perspectiva global e são os direitos sociais como a uma vida digna, a uma moradia descente, a uma saúde pública, à previdência social, à educação, etc. É o chamado direito coletivo de povos e nações e que por culpa da pobreza, da ignorância, da imigração econômica para os países mais ricos, das guerras por motivos algumas vez étnicos ou por outros tipos de intolerâncias radicais que levam a genocídios e matanças sem precedentes, da exploração econômica de forma primitiva da natureza que leva a um deterioro das últimas reservas que o 
planeta possui, etc., certamente é um direito difuso, transfronteiriço e por isso uma questão de direito transnacional.

Trata-se de um típico tema da época da guerra fria, da dicotomia entre países ricos e pobres, e que foi positivado como direitos humanos a partir dos Pactos Internacionais de Direitos Humanos, uma vez que tanto no Pacto de Direitos Civis e Políticos como no Pacto de Direitos Econômicos, Sociais e Culturais está previsto no artigo $1^{\circ}$ de ambos pactos como conseqüência do direito à autodeterminação dos povos. Também são muito bem definidos na Declaração sobre o Direito ao Desenvolvimento aprovada pela Resolução n.41/128 da Assembléia Geral das Nações Unidades, em Paris, em 4 de dezembro de 1986: "O direito ao desenvolvimento é um direito humano inalienável em virtude do qual toda pessoa humana e todos os povos estão habilitados a participar do desenvolvimento econômico, social, cultural e político, a ele contribuir e dele desfrutar, no qual todos os direitos humanos e liberdades fundamentais possam ser plenamente realizados" (artigo $\left.1^{\circ}\right)^{63}$. E trazido à tona novamente com a Declaração e Programa de Ação de Viena de 1993 (pontos 1.9, 1.10 e 1.11). Ainda que não devemos excluir os esforços da Comunidade Internacional, da mesma maneira pensamos como o professor Peces-Barba quando argumenta que o direito ao desenvolvimento tem problemas teóricos no que diz respeito aos seus titulares ${ }^{64}$, mas que estas dificuldades seriam superados se consideramos a possibilidade de um Direito transnacionalizado e com uma nova visão da titularidade especificada dos direitos humanos.

De todas as formas, não resta dúvida que para o bem da humanidade algo deve ser mudado. O conceito de desenvolvimento sustentável talvez seja uma das grandes falácias de nossa era que certamente nos passará uma conta de destruição da natureza no futuro. Certamente que um mundo melhor é possível, citando aqui propositalmente o lema dos seguidos Fóruns Sociais, outros modelos de desenvolvimento são possíveis, e este paradigma deve ser procurado com 0 emprenho de toda a Comunidade Internacional.

\section{FUNDAMENTAÇÃO DO FENÔMENO DA TRANSNACIONALIDADE}

Para caracterizar a necessidade de transnacionalização dos direitos fundamentais de terceira geração, faz-se necessário reflexionar sobre os seguintes aspectos: o objeto de proteção do direito transnacional; o fundamento moral da transnacionalização; o espaço político e jurídico a ser matizada a transnacionalização.

O objeto de proteção seriam os anteriormente vistos direitos de terceira geração (resultantes do processo de especificação), as demandas transnacionais a serem protegidas seriam interesses coletivos e difusos e não somente os estritamente individuais, como querem os defensores de uma estrita globalização econômica de cunho neoliberal ${ }^{65}$. A definição dos interesses coletivos a serem considerados como objetos a serem protegidos exige, sem nenhuma dúvida, certas condições que permitam que sua acepção seja verdadeiramente racional e fundamentada e por isso confiável. Necessariamente deve tratar-se de temas universalizáveis, evidentemente de interesse de toda a humanidade, pelo tal devem estar excluídos interesses privados de uma classe privilegiada ou a imposição de simples interesses estratégicos das mesmas que por definição não podem ser 
universalizáveis por se apresentarem incompatíveis com a questão da igualdade perante a lei. Deve ser superado o esquema público/privado e, ainda que a primeira vista pareça contraditório, deve-se dar a imposição incondicionada do individuo sobre a comunidade ${ }^{66}$ e do interesse público sobre 0 privado (princípio republicano) ${ }^{67}$.

Uma vez que o fundamento e o valor guia dos direitos fundamentais de primeira geração é a liberdade, assim como o valor guia igualdade é o fundamento para os direitos de signo econômico, social e cultural, os direitos de terceira geração têm como principal valor de referência e fundamento a contemporânea idéia de solidariedade, que deriva da moderna idéia de fraternidade.

O fundamento moral da transnacionalização do direito seria então a solidariedade que, entendida em um sentido lato sensu exigirá a superação do sentimento de etnocentrismo ${ }^{68}$, inerente à formação do Estado nacional moderno (típico do Estado imperalista-canalha na concepção de Danilo Zolo, Ernesto Garzón Valdés, Immanuel Wallerstein, Joaquín Herrerra Flores e Jacques Deriva ${ }^{69}$ ), ou seja, a ampliação da noção de sociedade e de nação e a inclusão do círculo do pronome nós aos que antes se considerava eles (na concepção de Jürgen Habermas ${ }^{70}$ ). Dito de outra forma: a superação da dicotomia nós/eles, sobretudo da dialética amigo/inimigo, e das perspectivas antropológicas que vêm ao homem como um ser isolado que não pode ou que não deve estabelecer laços de união com seu entorno. Fundamental é a questão da solidariedade para a superação do trauma da sociedade hobbesiana (o homem é o lobo do homem) e ao tratar-se de substituir esta visão pela de um homem inserido em uma comunidade transnacional, ciente de dificuldades comuns a todos, questões estas inevitavelmente difusas, e por isso aberta ao debate. Certamente que na sociedade transnacionalizada existem muitos interesses em comum de chegar a um acordo, de preferência a um consenso, sobre problemas a que todos afetam. Estes problemas seriam as demandas de transnacionalização do direito: como o problema das guerras, da destruição do planeta seja pela corrida armamentista desenfreada (como exemplo a questão das tecnologias nucleares agora em mãos de diversos países), ou pela degradação do meio ambiente, que como se sabe que cada dia se agrava mais e mais. Ademais do problema do direito dos consumidores, assim como a regulação e proteção dos direitos dos trabalhadores, em uma economia globalizada, etc. ${ }^{71}$.

Evidentemente que ao tratar-se de questões como as do parágrafo anterior deve-se ter em conta a prolixa obra de Jürgen Habermas, dita obra deve ser objeto de estudo aprofundado para traçar os rumos de uma efetiva transnacionalização do direito. Habermas expôs em um grande número de trabalhos os pressupostos do discurso da superação da dialética do amigo/inimigo com a universalidade dos princípios republicanos e das perspectivas antropológicas da construção de nossa era $^{72}$. Exatamente, na linha do pensamento habermasiano, a cultura da solidariedade exigirá a superação das estruturas de dominação e sua substituição se deve dar por estruturas de cooperação, ou seja, por um Direito transnacional.

Quanto ao espaço político e jurídico necessário para a articulação das demandas transnacionais, estas exigiram uma certa forma de republicanismo, que se apoiaria em modelos educativos muito concretos e, que em alguma medida, traria uma maior implicação do cidadão em assuntos políticos. Cada vez mais assistimos 
um afastamento do cidadão aos centros de decisões, ou seja, cada vez mais um individualismo egoísta toma conta da vida de todos e a cidadania que fica sem verdadeiros representantes.

Evidentemente que a questão da educação do cidadão está intimamente conectada com a questão da participação do mesmo em dito espaço público. Somente um cidadão educado poderá se interessar pelos assuntos de sua comunidade e das demais comunidades conectadas a uma determinada demanda comum. Uma educação que invista no aprendizado dos direitos fundamentais e da cidadania, que desenvolva o argumento a favor dos direitos de todos, dos direitos de cidadania e que considere o dialogo como forma de resolver os conflitos. Conhecer, estudar os processos que levam aos conflitos e a violação de direitos fundamentais de primeira, segunda e terceira geração, certamente é mais do que aprender a solucioná-los, uma vez que o conhecimento é o primeiro e certeiro passo para prevenir e assim criar condições para posteriormente, com conhecimento de causa, solucionar as referidas demandas.

Uma questão a ser matizada é que a transnacionalização não poderia, em nenhuma hipótese, isolar ainda mais o cidadão dos centros de poder, pelo contrário, caberá reforçar sua participação e a garantia de seus interesses e direitos fundamentais, isso se daria através da chamada democracia participativa, como vemos hoje em dia no seio da União Européia. Ademais, não seria a total superação do Estado nacional, mas sim sua abertura para a resolução de problemas comuns inerentes a toda a família humana. Uma vez que não podemos mais pretender a superação de problemas globais e difusos de forma individual.

Então como republicanismo pode-se entender, em nossa opinião, como a vinculação de uma democracia participativa que ampliaria seu espaço de reflexão, debate e deliberação e que permitiria uma maior e melhor comunicação entre a política institucionalizada e a não institucionalizada. A denominada democracia representativa, que corresponde (ainda!) ao esquema liberal, e a sua via canalizada a partir dos partidos políticos, tem-se demonstrado ser absurdamente insuficiente para absorver as questões realmente de interesse público (interesse dos representados) e o complexo contexto de suas demandas. A crise da democracia representativa, nos moldes tradicionais como a brasileira, não é e nem deve ser considerada a crise da democracia, pois infelizmente a falta de credibilidade do sistema representativo trás como conseqüência o descrédito e a falta de interesse da grande maioria população e conseqüentemente leva ao distanciamento da tomada de decisões de uma ampla parte da população, em beneficio é claro de uma minoria oportunista.

A única saída seria a superação de modelos educativos atuais e a inclusão das discussões de questões relacionadas com os direitos fundamentais e cidadania no dia-a-dia da sala de aula e também sua inclusão na mídia em todos os níveis. Também a mídia e os escusos interesses que defende tem a sua parcela de culpa pela não efetividade dos direitos fundamentais em uma sociedade como a brasileira, isso certamente se deve à sua falta de compromisso com a ética e com a verdade sintetizados numa verdadeira banalidade do mal dos meios de comunicação para aqui citar o dizer de Hannah Arendt $^{73}$. A alusão à clássica autora nos faz justamente recordar as interessantes críticas de Joaquin Herrera ${ }^{74}$ no sentido de que em nossa 
sociedade valoriza o holocausto ocorrida na Segunda Guerra mundial, certamente que corretamente, mas se esquece da maldade e dos outros holocaustos mais recentes e de nossa atual sociedade, dando uma perversa idéia de que vivemos em uma sociedade quase perfeita e sem maldade, traduzindo-se assim a tendência de diminuir os problemas dos outros, dos excluídos e dos países periféricos, pelas classes dominantes e pelos países centrais ${ }^{75}$.

Com a transnacionalização dos direitos fundamentais o compromisso de um país periférico passaria a ser com toda a comunidade transnacional a que pertence, e não mais somente com o seu (des)enganado povo. Seria uma aposta para diminuir o problema de constitucionalização do faz de conta dos direitos fundamentais, problema tão bem explicado por Marcelo Neves na tese do livro $A$ Constitucionalização simbólica ${ }^{76}$, e irreverentemente sintetizada como as promessas (a constitucionalização dos direitos fundamentais) do amante (o Estado) à suposta amada (representada pelo povo) na interessante explicação do professor Luís Alberto Warat sobre o exercício da atividade jurisdicional do Estado nacional com relação à aplicação das regras jurídicas relativas aos direitos fundamentais previstos na Constituição: "(...) como promessas de amor, aquelas que os amantes formulam quando sabem que não poderão cumpri-las" ${ }^{\text {"77. }}$.

Noberto Bobbio em um de seus escritos mais inspirados e adiantados ao seu tempo, como o próprio título prevê, $O$ futuro da democracia ${ }^{78}$, apresentava os problemas e as dicotomias que a democracia enfrentava e que viria a enfrentar no futuro: os interesses particulares contra o bem de todos (exemplo dos nossos dias: a pouca valorização atual do princípio republicano); o governo das elites contra o governo do povo (idem); a ausência de um espaço público de debate e de uma genuína participação popular (a apatia cidadã e a atual crise de representatividade de nossos parlamentos); o cidadão insuficientemente formado (a péssima educação atual da maioria da população); e entre outras questões a persistente ingovernabilidade das democracias (o abuso das medidas provisórias em nosso sistema). Diante do panorama aludido, Bobbio apontava algumas linhas básicas para uma renovação da democracia com uma efetiva participação cidadã: renovação da sociedade mediante um livre debate de idéias; uma mudança de mentalidade a favor dos ideais de direitos humanos; mudança de valores a favor da não violência, da tolerância e do ideal de fraternidade. Em todos os casos dentro do sistema fechado dos Estados Nacionais vemos que os Estados estão passando, mesmos os sistemas democráticos, por problemas gravíssimos comuns a todos como a corrupção, a dominação das elites e de seus interesses, a infidelidade aos seus ideais mesmo a falta de ideologias por parte dos partidos políticos e a conseqüente apatia política cidadã e por fim o aumento das desigualdades sociais.

Os novos direitos fundamentais se encontram conectados entre si exatamente por sua incidencia universal na vida de todos os homens e exigem para sua realização a comunidade de esforços e sobretudo responsabilidades de todo o planeta $^{79}$.

Certamente que com o objeto de proteção bem localizado e os objetivos bem claros da sociedade transnacionalizada, assim como bem entendida a fundamentação teórica da transnacionalização, e uma conseqüente abertura de espaços políticos para o debate, o resultado será uma boa regulação do Direito 
Transnacional.

\section{CONCLUSÃO}

O processo de internacionalização tradicional dos direitos humanos, a partir da criação dos sistemas internacionais de proteção dos direitos humanos - universal: ONU e regionais: OEA e Conselho de Europa - não têm se mostrado suficientes para a proteção dos direitos fundamentais de primeira e segunda geração e nem o serão para questões mais complexas como os de terceira geração. Fica então evidente a necessidade de criação de um espaço transnacional para que a Comunidade Internacional possa proteger questões tão urgentes para o ser humano como a paz entre as nações, a defesa do consumidor global, o meio ambiente para a atual e as futuras gerações, o crime organizado internacionalmente e outras novíssimas questões relacionadas com novas tecnologias como a biotecnologia evolução da medicina - e o ciberespaço mundial.

Os direitos fundamentais de terceira geração também são reivindicações dos mais débeis, quando vemos que questões como a paz, o meio ambiente, o consumo, a proteção da criança e do adolescente, do idoso etc., são mais débeis que os interesses econômicos das grandes corporações e dos Estados centrais. Quando estão em jogo interesses econômicos dos mais poderosos sabemos que prevalecem quase sempre a vontade dos de sempre. Como o vulnerável súdito do estado absoluto, como o desprotegido trabalhador no estado liberal de direito do século XIX, o cidadão atual tem a necessidade de ver suas demandas fortalecidas pela construção de um espaço transnacional que venha a proteger suas demandas mais recentes ("novos" direitos).

A evidente crise da democracia e do Estado nacional leva a que devam ser pensadas novas possibilidades para regular e renovar as questões de cidadania. A União Européia certamente é o exemplo de transnacionalização que superou a questão puramente econômica e com respeito à decisão das maiorias e de uma sublime invocação, consideração e respeito aos direitos fundamentais mudou o rumo de futuras alianças transnacionais.

O fenômeno da transnacionalidade é mais bem caracterizado então como conseqüência do processo de especificação. Como um fenômeno recente e que está interligado aos chamados "novos" direitos, novos direitos fundamentais.

\section{REFLECTIONS ON THE PHENOMENON OF "NEW " FUNDAMENTAL RIGHTS AND TRANSNATIONAL CLAIMS.}

\section{ABSTRACT}

This article seeks to demonstrate the existing connection between the concept of new fundamental rights and the phenomenon of transnationalization of rights. It establishes that this connection starts with the historical process of specifying fundamental rights. In addition it analyses the concept and characteristics of the new 
transnational fundamental rights, and beginning with a series of identifying and determining criterion, selects which demands are the foundation for these rights. Finally, some groundwork is presented for the transnational phenomenon which will be involved not only in the creation of a new democratic space between countries but also in a new vision of rights.

Keywords: Fundamental rights. New rights. Transnationalization.

\section{NOTAS}

1 Doutor em Direito pela Universidade Complutense de Madrid - Espanha. Professor do Programa de Pós-Graduação Stricto Sensu em Ciência Jurídica - Cursos de Mestrado e Doutorado - e da graduação em Direito da Universidade do Vale do Itajaí (UNIVALI). Email:mleitegarcia@terra.com.br. Endereço: Universidade do Vale do Itajaí, Pró-reitoria de Pesquisa Pós-graduação Extensão e Cultura, Curso de Pós Graduação Stricto Sensu em Ciência Jurídica - Rua Uruguais, 458, Bloco 16, 3o piso - Centro - 88302202 - Itajaí, SC - Brasil.

2 HABERMAS, Jürgen. Era das transformações. Rio de Janeiro: Tempo Brasileiro, 2003. Título original: Zeit der Übergänge.

3 HABERMAS, Jürgen. A constelação nacional: Ensaios políticos. Tradução de Marcio SeligmannSilva. São Paulo: Littera Mundi, 2001. Título original: Die postnationale Konstellation: Politischen Essays.

4 HABERMAS, Jürgen. Era das transformações. Especificamente capítulo 2, p. 37-74.

5 HABERMAS, Jürgen. Era das transformações. Especificamente capítulo 6, p. 175-193.

6 "No se puede hablar propiamente de derechos fundamentales hasta la modernidad. Cuando afirmamos que se trata de un concepto histórico propio del mundo moderno, queremos decir que las ideas que subyacen en su raíz, la dignidad humana, la libertad o la igualdad por ejemplo, sólo empiezan a plantear desde los derechos en un momento determinado de la cultura política y jurídica. Antes existía una idea de la dignidad, libertad y igualdad que encontramos dispersa en autores clásicos como Platón, Aristóteles o Santo Tomás, pero éstas no se unifican en ese concepto". PECES-BARBA, Gregorio. Curso de Derechos Fundamentales: teoría general. Madrid: Universidad Carlos III de Madrid, 1995. p. 113-114.

7 Segundo reza a tradição o Direito Natural Racionalista teria sido concebido quase que por acaso a partir da tese do holandês Hugo Grotius, no histórico livro De Jure Belli ac Pacis (publicado em 1625), no sentido de que o Direito Natural existiria ainda que Deus não existisse, por ser tratar de direitos naturais de um ser racional "(...) o que não pode ser concebido sem um grande crime, isto é, que não existiria Deus ou que os negócios humanos não são objeto de seus cuidados". GROTIUS, Hugo. O Direito da Guerra e da Paz. Volume I. ljuí: Ed. Unijuí, 2004. p. 40. Ainda que devemos considerar a crítica de Herrera Flores que coloca em dúvida as verdadeiras intenções de Grotius (HERRERA FLORES, Joaquín. Los derechos humanos como productos culturales: crítica al humanismo abstracto. Madrid: Catarata, 2005. p. 94), não resta dúvida que será a partir dessa concepção de Direito Natural do pensador holandês que os seguintes autores passaram a tratar a questão de forma diferente do Direito Natural Clássico de transfundo religioso e conseqüentemente o direito natural passa a ser gradativamente separado da religião pelos seguintes e históricos livres pensadores como Samuel Pufendorf, Chistian Wolf e Chiristian Thomasius entre outros. Sobre a questão em pauta, ver: GARCIA, Marcos Leite. A contribuição de Christian Thomasius ao processo de formação do ideal dos direitos fundamentais. In: MARTEL, Letícia de Campos Velho (Org.). Estudos Contemporâneos de Direitos Fundamentais. Rio de Janeiro: Lumen Juris, 2009. p. 3-26.

8 Sobre a polêmica que resulta da dificuldade de classificar o direito à paz como direitos humanos são interessantes as seguintes palavras, e o citado artigo, de Maria Eugenia Rodríguez Palop: "Sé muy bien que la defensa del derecho a la paz como derecho humano no solo no es habitual sino que ha sido agresivamente contestada por una buena parte de los teóricos que se dedican a estos temas, con el agravante de que algunas de tales criticas están ampliamente fundadas. El derecho a la paz, además no ha sido ni suficientemente estudiado, ni analizado en profundidad, sino que da la impresión de que ha salido del campo de juego antes de empezar a jugar. Y eso es lo que, me parece, hay que intentar evitar. Evitar un fundamentalismo de los derechos humanos que nos lleve a excluir, sin discutirlas, demandas que se encuentran frecuentemente en el espacio 
público y que han sido enarboladas por un gran número de movimientos sociales". RODRÍGUEZ PALOP, María Eugenia. El derecho a la paz: un cambio de paradigma. In: CAMPOY CERVERA, Ignacio; REY PÉREZ; José Luis; (Orgs.). Desafíos actuales de los derechos humanos: reflexiones sobre el derecho a la paz. Madrid: Dykinson, 2006. p. 51. Da mesma maneira um interessante debate sobre o direito à paz em: RUIZ MIGUEL, Alfonso. Tenemos derecho a la paz? Anuario de Derechos Humanos, n. 3, 1985, p. 397-434.

Veja por exemplo as declarações resultantes das revoluções burguesas, u Veja por exemplo as declarações resultantes das revoluções burguesas, uma vez que tanto a
Declaração dos Direitos do Homem e do Cidadão de 1789, assim como a Declaração de Independência Americana de 1776, se referem a um cidadão universal. Ver os referidos documentos em: COMPARATO, Fábio Konder. A afirmação histórica dos Direitos Humanos. 5.ed. São Paulo: Saraiva, 2007. Respectivamente p. 158 e p. 108. Sobre a questão da universalidade dos direitos humanos fundamentais ver em termos gerais sua defesa em PÉREZ LUÑO. AntonioEnrique. La Universalidad de los Derechos Humanos y el Estado Constitucional. Bogotá: Universidad Externado de Colombia. 2002. Uma interessante e diferente defesa da universalidade dos direitos humanos encontramos no excelente texto do indiano Amartya Sen: SEN, Amartya. Desenvolvimento como Liberdade. São Paulo: Companhia das Letras. 2000. Ainda o tema é de maneira inteligente tratado por Jesús González Amuchastegui, infelizmente recentemente falecido o professor espanhol nos deixou um excelente legado, em: GONZÁLEZ AMUCHASTEGUI, Jesús. Autonomía, dignidad y ciudadanía: Una teoría de los derechos humanos. Valencia: Tirant lo Blanch, 2004. E uma inteligente e madura crítica em WALLERSTEIN. Immanuel. O universalismo Europeu: a retórica do poder. São Paulo: Boitempo, 2007. Da mesma forma impossível não citar a interessantíssima e atual crítica de Joaquín Herrera Flores em: HERRERA FLORES, Joaquín. Los derechos humanos como productos culturales: crítica del humanismo abstracto. Madrid: Catarata, 2005.

Norberto Bobbio conclama a Declaração de 1948 como o documento mais importante da história da humanidade, uma que na opinião do filósofo italiano "(...) representa a manifestação da única prova através da qual um sistema de valores pode ser reconhecido: e essa prova é o consenso geral acerca da sua validade" (p. 26). Esta já é uma visão clássica que os diferentes autores de teoria geral dos direitos humanos discutem sua validade há algumas décadas. Conferir: BOBBIO, Norberto. Presente e futuro dos direitos do homem. In:

Carlos Nelson Coutinho. Rio de Janeiro: Campus, 1992. p. 25-47.

13 Uma das primeiras dificuldades que apresenta o tema dos direitos é quanto a sua terminologia. Diversas expressões foram utilizadas através dos tempos para designar o fenômeno dos direitos fundamentais. Por exemplo, atualmente a expressão direito natural deve ser considerada como um termo histórico que significa ainda uma pretensão moral justificada não positivada como Direito. Em nossa opinião duas são as expressões mais corretas para serem usadas atualmente: direitos humanos e direitos fundamentais. Respaldamos nossa opinião no consenso geral existente na doutrina especializada no sentido de que o termo direitos humanos se utiliza quando fazemos referência àqueles direitos positivados nas declarações e convenções internacionais, e o termo direitos fundamentais para aqueles direitos que aparecem positivados e garantidos no ordenamento jurídico de um Estado. Da mesma forma que os distintos autores quando se referem à história ou à filosofia dos direitos humanos, usam, de acordo com suas preferências, indistintamente os aludidos termos. Então, para efeitos do presente trabalho sobre transnacionalidade as expressões direitos fundamentais e direitos humanos são sinônimas. Sobre o assunto e o consenso terminológico: PEREZ LUÑO, Antonio-Enrique. Derechos Humanos, Estado de Derecho y Constitución. 9. ed. Madrid: Tecnos, 2005. p. 31; BARRANCO, Maria del Carmen, El discurso de los derechos: Del problema terminológico al debate conceptual. Madrid: Dykinson, 1992. p. 20; e SARLET, Ingo Wolfgang. A eficácia dos direitos fundamentais. Porto Alegre: Livraria do Advogado, 2001. p. 33.

14 Este seria um processo diacrônico, ao mesmo tempo inicial e ainda atual que explica além do surgimento do ideal dos direitos fundamentais na Modernidade, também a constante transformação dos mesmos e sua adaptação às questões aqui estudas. Ver: GARCIA, Marcos Leite. O processo de formação do ideal dos direitos fundamentais: alguns aspectos destacados da gênese do conceito. In: XIV Congresso Nacional do Conpedi, 2005, Fortaleza, CE. Anais. Disponível em: http://www.org/manaus/arquivos/Anais/Marcos\%20Leite\%20Garcia.pdf>. Acesso em: 27 abr. 2009.

Entre outros trabalhos do professor espanhol, ver: PECES-BARBA, Gregorio. Las líneas de evolución de los derechos fundamentales. In: Curso de Derechos Fundamentales: teoría 
general. Madrid: Universidad Carlos III de Madrid, 1995. p. 146-198.

16 Certamente que a única organização na qual a internacionalização dos direitos humanos há dado frutos mais positivos, com uma visível autoridade supranacional, tenha sido no marco do sistema de proteção do Conselho de Europa, devido a que são sociedades mais homogêneas em sua cultura política e jurídica.

17 Para Carlos de Cabo Martín a solidariedade é um princípio básico do constitucionalismo do Estado social como contraponto de que a insolidariedade é um suposto básico do constitucionalismo liberal. CABO MARTíN, Carlos de. Teoría Constitucional de la solidariedad. Madrid: Marcial Pons, 2006. Respectivamente p. 45- 107 e p. 39-44.

18 AÑON ROIG, Maria José. Necesidades y Derechos. Madrid: Centro de Estudios Constitucionales, 1994. p. 45.

19 Muito outros exemplos poderiam ser aludidos, como o clássico exemplo de uma guerra entre duas nações, violação do pretendido por alguns doutrinadores "novo" direito à paz, certamente trata-se de um outro caso de violação de um direito humano difuso exatamente porque uma guerra entre dois países poderá envolver outros países ou toda uma região ou mesmo a maioria dos países do globo terrestre e certamente trará conseqüências a todo o planeta sejam estas humanitárias, econômicas e/ou até ambientais.

20 Segundo se sabe em um livro de 1956, o primeiro autor a falar em um Direito Transnacional (Transnational Law) é o professor da Universidade de Colúmbia Philip C. Jessup. Conferir: JESSUP, Philip C. Direito Transnacional. Rio de Janeiro: Ed. Fundo de Cultura, 1965.

21 CRUZ, Paulo Márcio; BODNAR, Zenildo. A transnacionalidade e a emergência do Estado e do Direito Transnacional. v. 14, n. 1, jan./jun. 2009, p. 5.

22 CRUZ, Paulo Márcio; BODNAR, Zenildo. A transnacionalidade e a emergência do Estado e do Direito Transnacional. p. 6.

CRUZ, Paulo Márcio; BODNAR, Zenildo. A transnacionalidade e a emergência do Estado e do Direito Transnacional. p. 6. Editorial Aranzadi, 2006. p. 28 PÉREZ LUÑO, Antonio-Enrique. BOBBIO, Norberto. A era dos direitos. In: Coutinho. Rio de Janeiro: Campus, 1992. p. 62-63. PECES-BARBA, Gregorio. Lecciones de Derechos Fundamentales. Madrid: Dykinson, 2004. p. 120. BOBBIO, Norberto. A era dos direitos. p. 63

Para o professor Antonio-Enrique Pérez Luño o que caracteriza o direito da pós-modernidade são as questões que fazem parte de sua classifica de direitos fundamentais de terceira geração. PÉREZ LUÑO, Antonio-Enrique. La tercera generación de los derechos humanos. p. 53.

30 Será o professor Florestan Fernandes quem melhor explicará as origens da Modernidade no Brasil: "(...) a ordem escravocrata e senhorial não se abriu facilmente aos requisitos econômicos, sociais, culturais e jurídico-político do capitalismo. Mesmo quando eles se incorporavam aos fundamentos legais daquela ordem, eles estavam condenados à ineficácia ou a um entendimento parcial e flutuante, de acordo com as conveniências econômicas dos estamentos senhoriais". No mesmo sentido, segue o professor paulista "(...) Aqui cumpre ressaltar, em especial, a estreita vinculação que se estabeleceu, geneticamente, entre interesses e valores sociais substancialmente conservadores (ou em outras terminologias: particularistas e elitistas) e a constituição da ordem social competitiva. Por suas raízes históricas, econômicas e políticas, ela prendeu o presente ao passado como se fosse uma corrente de ferro. Se a competição ocorreu, em um momento histórico, para acelerar a decadência e o colapso da sociedade de casta e estamentos, em outro momento ela irá acorrentar a expansão do capitalismo a um privatismo tosco, rigidamente, particularista e, fundamentalmente, autocrático, como se o 'burguês moderno' renascesse das cinzas do 'senhor antigo'”. FERNANDES, Florestan. $A$ revolução burguesa no Brasil: Ensaio de interpretação sociológica. São Paulo: Zahar, 1975. Respectivamente p. 151 e p. 167-168 (grifo acrescentado).

31 FAORO, Raymundo. Os donos do poder: formação do patronato político brasileiro. 3.ed., São Paulo: Editora Globo, 2001. FERRAJOLI, Luigi. Derechos y garantías: la ley del más débil. Tradução de Perfecto A. Ibáñes e Andréa Greppi. Madrid: Trotta, 1999.

33 PECES-BARBA, Gregorio. Lecciones de Derechos Fundamentales. p. 120-122.

34 PECES-BARBA, Gregorio. Lecciones de Derechos Fundamentales. p. 121.

35 PECES-BARBA, Gregorio. Lecciones de Derechos Fundamentales. p. 121. 
Assim explicava o professor espanhol em suas aulas. PECES-BARBA, Gregorio. Concepto y fundamentación de los Derechos Humanos. Anotaciones de clases por alumnos del año académico 1988-1989. Asignatura del Curso de Doctorado en el Programa de Derechos Fundamentales - Instituto de Derechos Humanos - Universidad Complutense de Madrid. seria melhor utilizar a expressão grupos históricos de direitos fundamentais ou, ainda, somente grupos de direitos fundamentais. Grupos estes resultantes das linhas de evolução dos direitos fundamentais e de seus respectivos valores da trilogia da Revolução Francesa: processo de positivação - liberdade; processo de generalização - igualdade; processo de especificação fraternidade no sentido contemporâneo de solidariedade.

45 Ver: GARCIA, Marcos Leite. Efetividade dos direitos fundamentais: notas a partir da visão integral de Gregorio Peces-Barba. In: MARCELLINO JR. Julio Cesar; VALLE, Juliano Keller do. Reflexões da pós-modernidade: Estado, Direito e Constituição. Florianópolis: Conceito, 2008. p. 189-209.

PECE-BARBA, Gregorio. Curso de Derechos Fundamentales. p. 113-144.

Encontramos em María Eugenia Rodríguez Palop uma bela definição do directo à paz: "EI derecho a la paz podría suponer el derecho de un Estado (entendido, en sentido moral, como el derecho de todos y cada uno de sus ciudadanos) a no ser agredido violentamente por otros y, quizás también, el derecho frente al Estado de requerir la adopción de una política lícita mediante la cual no se ponga en peligro o se violen los derechos de terceras personas existentes o posibles $y$, en concreto, el de objeción de conciencia al servicio militar (aunque este último caso se 
canaliza por medio del ejercicio de las libertades civiles y se configure como un derecho de primera generación)". RODRÍGUEZ PALOP, María Eugenia. La nueva generación de derechos humanos: origen y justificación. Madrid: Dykinson, 2002. p. 110. PECES-BARBA, Gregorio. Curso de Derechos Fundamentales. p. 191-196.

50 Idéias expostas no livro: FERRAJOLI, Luigi. Razones jurídicas del pacifismo. Edição e tradução organizada por Gerardo Pisarello. Madrid: Trotta, 2004.

51 Sobre os diferentes tipos de pacifismos, assim como os diferentes tipos de belicismos, ver: RUIZ MIGUEL, Alfonso. La justicia de la guerra y de la paz. Madrid: Centro de Estudios Constitucionales, 1988. p. 81-119.

52 Grifados os conceitos teorizados por Ferrajoli. Sobre o tema ver: PISARELLO, Gerardo. Introducción: el pacifismo militante de Luigi Ferrajoli. In: FERRAJOLI, Luigi. Razones jurídicas del pacifismo. Edição e tradução organizada por Gerardo Pisarello. Madrid: Trotta, 2004. p. 11-24. Sobre o uso dos direitos humanos contra os próprios direitos humanos, ver o interessante livro sobre o assunto: ARCOS RAMIRÉZ, Federico. ¿Guerra en defensa de los derechos humanos? Problemas de legitimidad en las intervenciones humanitarias. Madrid: Dykinson, 2002.

Os crimes tipificados pelo Estatuto de Roma do Tribunal Penal Internacional estão expostos em seu artigo $5^{\circ}$ e conceituados em seus artigos 6ำ $7^{\circ}$ e $8^{\circ}$. Estes são: o crime de genocídio; crimes contra humanidade; crimes de guerra e o crime de agressão. Ver: PINTO, Antonio Luis de Toledo; et. al. (Col.) Legislação de Direito Internacional. São Paulo: Saraiva, 2008. p. 544-599.

Sobre o interessante tema do Direito Internacional Humanitário, regras humanitárias que devem ser obedecidas em caso de guerras declaradas - previstas sobre tudo nas Convenções de Genebra de 1948 (que trata da defesa dos não-combatentes: populações civis, feridos e enfermos e prisioneiros de guerra) -, recomenda-se a seguinte obra: SOUSA, Mônica Teresa Costa. Direito Internacional Humanitário. 2.ed. Curitiba: Juruá, 2007.

Ver nota 9 supra citada.

PÉREZ LUÑO, Antonio-Enrique. La tercera generación de los derechos humanos. p. 29. PÉREZ LUÑO, Antonio-Enrique. La tercera generación de los derechos humanos. p. 29. PÉREZ LUÑO, Antonio-Enrique. La tercera generación de los derechos humanos. p. 29. PÉREZ LUÑO, Antonio-Enrique. La tercera generación de los derechos humanos. p. 29. MARTÍN MATEO, Ramón. Tratado de Derecho Ambiental. Vol. I. Madrid: Trivium, 1991. p. 45. PECES-BARBA, Gregorio. Lecciones de Derechos Fundamentales. p. 125

3 PINTO, Antonio Luis de Toledo; et. al. (Col.) Legislação de Direito Internacional. São Paulo: Saraiva, 2008. p. 481-484.

Sobre o tema do fenômeno da globalização neoliberal, o seguinte texto de Boaventura de Sousa Santos é muito elucidador: SANTOS, Boaventura de Sousa. Os processos de globalização. In: (org.). A Globalização e as ciências sociais. São Paulo: Cortez, 2002. p. 25-102. Da mesma maneira também é interessante: BECK, Urich. ¿Que es la globalización? Falacias del globalismo, respuestas a la globalización. Tradução de B. Moreno e M. R. Borrás. Barcelona: Paidós, 1998.

66 RODRIGUES PALOP, Maria Eugenia. Los intereses colectivos en el discurso de los derechos humanos. In: ANSUÁTEGUI ROIG, Francisco Javier (ed.). Una discussion sobre derechos colectivos. Madrid: Dykinson, 2001. p. 271-287.

67 Sobre a questão do princípio republicano veja-se: CRUZ, Paulo Márcio; SCHMITZ, Sérgio Antonio. Sobre o princípio republicano. Revista Novos Estudos Jurídicos. Itajaí, v. 13, n. 1, p. 4354, jan./jun. 2008.

68 Etnocentrismo: "Neologismo formado a partir da expressão grega éthnos (raça) e da latina centrum (centro). Tendência dos indivíduos a tomar sua própria cultura como superior e como centro, modelo de referência e norma. Rechaça, por tanto, a diversidade cultural". RUSS, Jacqueline. Léxico de Filosofía: Dictionnarie de Philosofie. Madrid: Akal, 1999. p. 141. Duas outras definições de etnocentrismo: 1). "Rechaço a admitir o fato mesmo da diversidade cultural; preferese expulsar fora da cultura, ao âmbito da natureza, tudo que não se conforma à norma baixo a qual se vive". LÉVI-STRAUSS, Claude. Le Racisme de l'homme. Paris: Unesco/Gallimard, p. 246. Apud: RUSS, Jacqueline. Léxico de Filosofía: Dictionnarie de Philosofie. p. 141. 2). Etnocentrismo: (...) tentativa de situar no centro do universo - e considerar como a medida de qualquer valor - o próprio grupo étnico". MORIN, Edgar. Philosopher. Paris: Ed. Fayard, p. 41. Apud: RUSS, Jacqueline. Léxico de Filosofía: Dictionnarie de Philosofie. p. 141 (Traduções livres do autor)

69 Um bom estudo sobre a maldade estatal poderia ser feito a partir dos respectivos livros dos autores citados, ver: ZOLO, Danilo. Justicia de los vencedores: De Nüremberg a Bagdá. Madrid: 
Trotta, 2007; GARZÓN VALDÉS. Ernesto. Calamidades. Barcelona: Gedisa, 2004; WALLERSTEIN. Immanuel. O universalismo Europeu: a retórica do poder. São Paulo: Boitempo, 2007; HERRERA FLORES, Joaquín. Los derechos humanos como productos culturales: crítica del humanismo abstracto. Madrid: Catarata, 2005. DERRIDA, Jacques. Canallas: dos ensayos sobre la razón. Tradução de Cristina Peretti. Madrid: Trotta, 2005.

70 Ver: HABERMAS, Jürgen. A inclusão do outro: estudos de teoria política. São Paulo: Loyola, 2002.

71 Sobre o valor da solidariedade incluindo também direitos sociais, ver: CABO MARTíN, Carlos de. Teoría Constitucional de la solidariedad. p. 45- 107.

72 Por exemplo: HABERMAS, Jürgen. $A$ inclusão do outro: estudos de teoria política. Tradução de George Sperber e Paulo Astor Soethe. São Paulo: Loyola, 2002; e _ Direito e democracia: entre faticidade e validade. Volumes I e II. Tradução de Flavio Beno Siebeneichler. Rio de Janeiro: Tempo Brasileiro, 1997.

73 Ver: ARENDT, Hannah. Eichmann em Jerusalém: um relato sobre a banalidade do mal. Tradução de José Rubens Siqueira. São Paulo: Companhia das Letras, 1999. RRERA FLORES, Joaquín. Los derechos humanos como productos culturales. p. 67.

"Desde que las bombas de Hiroshima y Nagasaki dieron fin a la segunda guerra mundial se han calculado que la humanidad ha sufrido más de ciento y treinta guerras (dados de 1983) (...), cuyo resultado en muertos se cuenta por millones (...)". RUIZ MIGUEL, Alfonso. La justicia de la guerra y de la paz. p. 47.

77 WARAT, Luis Alberto. Apresentação fora das rotinas. In: ROSA, Alexandre Morais da. Garantismo jurídico e controle de constitucionalidade material. Florianópolis: Habitus, 2002. p. 13.

78 BOBBIO, Norberto. O futuro da democracia. 7.ed. Tradução de Marco Aurélio Nogueira. São Paulo: Paz e Terra, 2000.

79 PEREZ LUÑO, Antonio-Enrique. La tercera generación de los Derechos Humanos, p. 34-35.

\section{REFERÊNCIAS}

AÑÓN ROIG, Maria José. Necesidades y Derechos. Madrid: Centro de Estudios Constitucionales. 1994.

ARCOS RAMIRÉZ, Federico. ¿Guerra en defensa de los derechos humanos? Problemas de legitimidad en las intervenciones humanitarias. Madrid: Dykinson, 2002.

ARENDT, Hannah. Eichmann em Jerusalém: um relato sobre a banalidade do mal. Tradução de José Rubens Siqueira. São Paulo: Companhia das Letras, 1999. Título original: Eichman in Jerusalen: A Report on the Banality of Evil.

BARRANCO, Maria del Carmen, El discurso de los derechos: Del problema terminológico al debate conceptual. Madrid: Dykinson, 1992.

BECK, Urich. ¿Que es la globalización? Falacias del globalismo, respuestas a la globalización. Tradução de Bernardo Moreno e María R. Borrás. Barcelona: Paidós, 1998. Título original: Was is Globalisierung?

BOBBIO, Norberto. A era dos direitos. Tradução de Carlos Nelson Coutinho. Rio de Janeiro: Campus, 1992. Título original: L'età del Diritti.

BOBBIO, Norberto. O futuro da democracia. 7.ed. Tradução de Marco Aurélio Nogueira. São Paulo: Paz e Terra, 2000. Título original: Il futuro della democrazia. 
CABO MARTíN, Carlos de. Teoría Constitucional de la solidariedad. Madrid: Marcial Pons, 2006.

COMPARATO, Fábio Konder. A afirmação histórica dos Direitos Humanos. 5.ed. São Paulo: Saraiva, 2007.

CRUZ, Paulo Márcio; BODNAR, Zenildo. A transnacionalidade e a emergência do Estado e do Direito Transnacional. v. 14, n. 1, p. 1-25, jan./jun. 2009 (no prelo).

CRUZ, Paulo Márcio; SCHMITZ, Sérgio Antonio. Sobre o princípio republicano. Revista Novos Estudos Jurídicos. Itajaí, v. 13, n. 1, p. 43-54, jan./jun. 2008.

DERRIDA, Jacques. Canallas: dos ensayos sobre la razón. Tradução de Cristina Peretti. Madrid: Trotta, 2005. Título original: Voyous: Deux essais sur la raison.

FAORO, Raymundo. Os donos do poder: formação do patronato político brasileiro. 3.ed., São Paulo: Editora Globo, 2001.

FERNANDES, Florestan. A revolução burguesa no Brasil: Ensaio de interpretação sociológica. São Paulo: Zahar, 1975.

FERRAJOLI, Luigi. Derechos y garantías: la ley del más débil. Tradução de Perfecto A. Ibáñes e Andréa Greppi. Madrid: Trotta, 1999. Título original: /l diritto come sistema de garanzie.

FERRAJOLI, Luigi. Razones jurídicas del pacifismo. Edição e tradução organizada por Gerardo Pisarello. Madrid: Trotta, 2004.

HABERMAS, Jürgen. A constelação nacional: Ensaios políticos. Tradução de Marcio Seligmann-Silva. São Paulo: Littera Mundi, 2001. Título original: Die postnationale Konstellation: Politischen Essays.

HABERMAS, Jürgen. $A$ inclusão do outro: estudos de teoria política. Tradução de George Sperber e Paulo Astor Soethe. São Paulo: Loyola, 2002. Título original: Die Einbeziehung des Anderen: Studien zur politischen Theorie.

HABERMAS, Jürgen. Direito e democracia: entre faticidade e validade. Volumes I e II. Tradução de Flavio Beno Siebeneichler. Rio de Janeiro: Tempo Brasileiro, 1997. Título original: Faktizität und Geltung.

HABERMAS, Jürgen. Era das transformações. Rio de Janeiro: Tempo Brasileiro, 2003. Título original: Zeit der Übergänge.

HERRERA FLORES, Joaquín. Los derechos humanos como productos culturales: crítica del humanismo abstracto. Madrid: Catarata, 2005.

GARCIA, Marcos Leite. A contribuição de Christian Thomasius ao processo de formação do ideal dos direitos fundamentais. In: MARTEL, Letícia de Campos Velho (Org.). Estudos Contemporâneos de Direitos Fundamentais. Rio de Janeiro: Lumen Juris, 2009. p. 3-26. 
GARCIA, Marcos Leite. O processo de formação do ideal dos direitos fundamentais: alguns aspectos destacados da gênese do conceito. In: XIV Congresso Nacional do Conpedi, 2005, Fortaleza, CE. Anais. Disponível em: http://www.org/manaus/arquivos/Anais/Marcos\%20Leite\%20Garcia.pdf>. Acesso em: 27 abr. 2009.

GARCIA, Marcos Leite. Efetividade dos direitos fundamentais: notas a partir da visão integral de Gregorio Peces-Barba. In: MARCELLINO JR. Julio Cesar; VALLE, Juliano Keller do. Reflexões da pós-modernidade: Estado, Direito e Constituição. Florianópolis: Conceito, 2008. p. 189-209.

GARZÓN VALDÉS. Ernesto. Calamidades. Barcelona: Gedisa, 2004.

GONZÁLEZ AMUCHASTEGUI, Jesús. Autonomía, dignidad y ciudadanía: Una teoría de los derechos humanos. Valencia: Tirant lo Blanch, 2004.

GROTIUS, Hugo. O Direito da Guerra e da Paz. Volume I. tradução de Ciro Mioranza. Ijuí: Ed. Unijuí, 2004. Título original: De Jure Belli ac Pacis.

JESSUP, Philip C. Direito Transnacional. Rio de Janeiro: Ed. Fundo de Cultura, 1965. Título original: Transnational Law.

MARTÍN MATEO, Ramón. Tratado de Derecho Ambiental. Vol. I. Madrid: Trivium, 1991. p. 45.

NEVES, Marcelo. A constitucionalização simbólica. São Paulo: Martins Fontes, 2007.

PECES-BARBA MARTINEZ, Gregorio. Curso de Derechos Fundamentales: teoría general. Madrid: Universidad Carlos III de Madrid, 1995.

PECES-BARBA MARTINEZ, Gregorio. Lecciones de Derechos Fundamentales. Madrid: Dykinson, 2004.

PÉREZ LUÑO, Antonio-Enrique. Concepto e concepción de los derechos humanos. DOXA, Alicante-Espanha, n. 4, p. 47-66, 1987.

PEREZ LUÑO, Antonio-Enrique. Derechos Humanos, Estado de Derecho y Constitución. 9. ed. Madrid: Tecnos, 2005.

PÉREZ LUÑO. Antonio-Enrique. La tercera generación de los derechos humanos. Cizur Menor-Navarra: Editorial Aranzadi, 2006.

PÉREZ LUÑO. Antonio-Enrique. La Universalidad de los Derechos Humanos y el Estado Constitucional. Bogotá: Universidad Externado de Colombia. 2002.

PINTO, Antonio Luis de Toledo; et. al. (Col.) Legislação de Direito Internacional. São Paulo: Saraiva, 2008.

PISARELLO, Gerardo. Introducción: el pacifismo militante de Luigi Ferrajoli. In: 
FERRAJOLI, Luigi. Razones jurídicas del pacifismo. Edição e tradução organizada por Gerardo Pisarello. Madrid: Trotta, 2004. p. 11-24.

RODRÍGUEZ PALOP, María Eugenia. El derecho a la paz: un cambio de paradigma. In: CAMPOY CERVERA, Ignacio; REY PÉREZ; José Luis; (Orgs.). Desafíos actuales de los derechos humanos: reflexiones sobre el derecho a la paz. Madrid: Dykinson, 2006. p. 51-61.

RODRÍGUEZ PALOP, María Eugenia. La nueva generación de derechos humanos: origen y justificación. Madrid: Dykinson, 2002.

RODRIGUES PALOP, Maria Eugenia. Los intereses colectivos en el discurso de los derechos humanos. In: ANSUÁTEGUI ROIG, Francisco Javier (ed.). Una discusión sobre derechos colectivos. Madrid: Dykinson, 2001. p. 271-287.

RUIZ MIGUEL, Alfonso. Tenemos derecho a la paz? Anuario de Derechos Humanos, n. 3, 1985, p. 397-434.

RUIZ MIGUEL, Alfonso. La justicia de la guerra y de la paz. Madrid: Centro de Estudios Constitucionales, 1988.

RUSS, Jacqueline. Léxico de Filosofía: Dictionnarie de Philosofie. Madrid: Akal, 1999.

SANTOS, Boaventura de Sousa. Os processos de globalização. In:

Globalização e as ciências sociais. São Paulo: Cortez, 2002. p. 25-102. (org.). $A$

SARLET, Ingo Wolfgang. Eficácia dos Direitos Fundamentais. 2.ed. Porto Alegre: Livraria do Advogado, 2001.

SEN, Amartya. Desenvolvimento como Liberdade. Tradução de Laura Doninelli Mendes. São Paulo: Companhia das Letras. 2000. Título original: Development as freedom.

SOUSA, Mônica Teresa Costa. Direito Internacional Humanitário. 2.ed. Curitiba: Juruá, 2007.

WALLERSTEIN. Immanuel. O universalismo Europeu: a retórica do poder. Tradução de Beatriz Medina. São Paulo: Boitempo, 2007. Titulo original: European universalism.

WARAT, Luis Alberto. Apresentação fora das rotinas. In: ROSA, Alexandre Morais da. Garantismo jurídico e controle de constitucionalidade material. Florianópolis: Habitus, 2002.

WOLKMER, Antônio Carlos. Introdução aos fundamentos de uma Teoria Geral dos "novos" Direitos. In:___ _ LEITE, José Rubens Morato (orgs.). Os "novos" Direitos no Brasil: natureza e perspectiva. São Paulo: Saraiva, 2003. p. 1-30.

ZOLO, Danilo. Justicia de los vencedores: De Nüremberg a Bagdá. Tradução de 
Elena Bossi. Madrid: Trotta, 2007. Título original: La giustizia dei vincitori.

Recebido para publicação: 2/12/2010

Aceito para publicação: 23/12/2010 